\title{
HasanuddinLawReview
}

\section{Initiating the Community Economic Improvement through Intellectual Property Registration of "Robusta Pinogu Coffee"}

\author{
Ibrahim Ahmad', Hasbir Paserangi ${ }^{2}$ \\ ${ }^{1}$ Faculty of Law, Gorontalo University, Indonesia. E-mail: ibrahim_ahmad22@yahoo.co.id \\ 2 Faculty of Law, Hasanuddin University, Indonesia. E-mail: hasbir_paserangi@yahoo.co.id
}

\author{
ARTICLE INFO \\ Keywords: \\ Geographical Indication; \\ Intellectual Property Right; \\ Pinogu Coffee \\ How to cite: \\ Ahmad, I., and Paserangi, \\ $H$. (2018). Initiating the \\ Community Economic \\ Improvement through \\ Intellectual Property \\ Registration of "Robusta \\ Pinogu Coffee". \\ Hasanuddin Law Review, \\ 4(1): 103-112 \\ DOI: \\ 10.20956/halrev.v4i1.1324
}

\begin{abstract}
Robusta Pinogu coffee was well known in both domestic and international markets, with production centers located in Pinogu subdistrict, Bone Bolango Regency, Gorontalo Province, Indonesia. It has unique flavor quality and good reputation in local, national and international markets. Its reputation tends to be counterfeited by irresponsible parties, which would harm producers and consumers of Robusta Pinogu coffee. Related to that, then "Masyarakat Indikasi Geografis Kopi Robusta Pinogu Bone Bolango" (MIG-KRPBB) be aware the need to have geographical indications for Robusta Pinogu coffee. Therefore, MIG-KRPBB submits for registration of geographical indication of Robusta Pinogu coffee to the Government of the Republic of Indonesia through the Ministry of Justice and Human Rights of the Republic of Indonesia based on the prevailing laws and regulations. This research was conducted in Bone Bolango Regency, Gorontalo Province. It is a legal research by using normative and empirical approaches. The results show that the Robusta Pinogu coffee in the market will be more secure than counterfeiting by parties who are not entitled to use the mark of Geographical Indication of Robusta Pinogu Coffee. however, it is expected to realize legal protection in the form of registration of geographical indication of Robusta Pinogu coffee for coffee farmer community so as to increase their economic level.
\end{abstract}

Copyright @ 2018 HALREV. All rights reserved.

\section{Introduction}

Geographical indication is a mark that unwittingly has been around for a long time and can indirectly indicate specificity of an item produced from a certain region. ${ }^{1}$ Then, it is used to indicate the origin of an item, whether in the products of agricultural, foodstuffs, handicrafts, or other goods, including raw and/or processed products, derived from

1 Saidin, O.K. (2015). Transplantation of Foreign Law into Indonesian Copyright law: The Victory of Capitalism Ideology on Pancasila Ideology. Journal of Intellectual Property Rights, 20(4): 230-249. 
agricultural or mining products. The designation of the origin of an item is important, due to the influence of geographical factors including natural, human, or a combination of these two factors in a particular region where the items are produced can provide the uniqueness and quality of the items and can be maintained within a certain period of time and makes reputation (famous) of the items and allows the items to have high economic value. ${ }^{2}$

Pinogu is a name of subdistrict in Bone Bolango Regency, Gorontalo Province. It is one of the regions in Gorontalo with interesting natural conditions. It is interesting because it belongs to the eastern part of Indonesia, where two tectonic plates collide between the Eurasian and the Pacific Ocean from the east-ward. Certainly, these conditions have many implications for life that goes on it. It located in the middle of the Tilongkabila mountains in the jungle forest of the National Park of Bogani Nani Wartabone.

The centers of planting and processing for robusta coffee in Pinogu subdistrict are located in all villages; Dataran Hijau, Pinogu, Bangio, Tilonggibila and Pinogu Permai. In addition to these natural factors, Pinogu also has the advantage of human factors. Robusta Pinogu coffee is a product that has high quality and reputation, because it is grown by people who have concern for the quality that is incorporated in the groups of farmer, processing and merchant who join in MIG-KRPBB as established based on Reagent' Decision of Bone Bolango No. 234/E/BUO-BB/ 113/2015, dated 7 September 2015, on the establishment of "Masyarakat Indikasi Geografis Kopi Robusta Pinogu Bone Bolangu" (MIG-KRPBB). This organization aims to always maintain the quality and reputation of robusta coffee they produce. The combination of natural and human factors in the region produces robusta coffee with unique flavor and quality and wellliked by the market both domestic and international markets and known as Robusta Pinogu coffee in the form of grain, roasted and powder coffees.

To protect the reputation of Robusta Pinogu coffee from counterfeiting by irresponsible parties, MIG-KRPBB submits application for registration of geographical indication of Robusta Pinogu coffee to the Ministry of Justice and Human Rights of the Republic of Indonesia. With the presence of the Geographical Indication of Robusta Pinogu coffee, it is hoped that it will be able to provide an additional attraction for national and international consumers ${ }^{3}$ to Robusta Pinogu coffee, since it is a guarantee against the original origin and quality of Robusta Pinogu coffee.

In addition, the registration of geographical indications of Robusta Pinogu coffee is intended to increase the added value and its competitiveness, especially in terms of: (1) legal protection for product names and production area; (2) recognition of product quality and specificity; and (3) preserve traditions of Robusta coffee production procedures that have been present in Pinogu subdistrict that spread throughout the village; Dataran Hijau, Pinogu, Bangio, Tilonggibila and Pinogu Permai.

2 The Directorate of General of Intellectual Property Rights the Ministry of Justice and Human Rights of the Republic of Indonesia, Kompilasi Undang-Undang Republik Indonesia di Bidang Hak Kekayaan Intelektual, Japan Internasional Co-operating Agency.

3 Rahmatullah, I. (2014). Perlindungan indikasi geografis dalam hak kekayaan intelektual (hki) melalui ratifikasi perjanjian lisabon. Jurnal Cita Hukum, 2(2): 305-316 


\section{Method}

This research is a legal research by using normative (statute and historical) and empirical approaches, it is intended to analyze legal aspect (normative) and legal-sociology (empirical) to impact the legal protection of the right of geographical indication of Robusta Pinogu coffee in Bone Bolango Regency, Gorontalo Province, through data collection techniques were direct interviews, questionnaires and daily report. The data were processed with qualitative and descriptive analysis techniques.

\section{Characteristics and Unique Properties of "Robusta Pinogu Coffee"}

There are 3 (three) elements contained in TRIP that need to be scrutinized by countries that intend to adapt their national legislation in the field of Intellectual Property Right. The three of elements are new norms, higher standards, and strict law enforcement. Approval of TRIPs is held with a view to reducing distortion and impediments in international trade and the need to promote effective and adequate protection against Intellectual Property Right and to ensure that process and law enforcement measures of Intellectual Property Right are not a barrier to trade. ${ }^{4}$

Geographical indication as intended in TRIPs agreement is a mark that identifies a territory of a member country, or area within the territory as the origin of the items, in which the reputation, quality, and characteristics of the items concerned are determined by the geographical factor. ${ }^{5}$ Under such provision it is understandable that the origin of an item attached to the reputation, characteristics, and quality of an item associated with a particular area is protected by juridical. The positive role of the original name of the item of the goodwill or other characteristics which may directly increase the economic advantage of the trade in goods must exist. In short, the name itself must have a reputation. Reputation is one of the protection elements mentioned explicitly by TRIPs agreement. ${ }^{6}$

The registration of Geographical Indications of Robusta Pinogu coffee is based on the following considerations:

(1) Robusta Pinogu Coffee originates from a specific area of hills and mountains Tilongkabila with an altitude between 300 to 400 meters from sea level. The ecosystem of coffee plantation at this altitude is perfect for Robusta coffee, that spread in Dataran Hijau, Pinogu, Bangio, Tilonggibila and Pinogu Permai, Pinogu subdistrict which has a soil type of red-yellowish Alfisol (Mediteran) with $\mathrm{pH} 6.25$.

(2) Robusta Pinogu coffee has a long history and a good quality reputation and has evolved into "origin coffee" in Indonesia with the typical flavor quality of Pinogu coffee has been well known in both domestic and international markets.

(3) Robusta Pinogu coffee business practitioner has a strong institution so that in doing its coffee business can share knowledge and skills.

Robusta Pinogu coffee is produced from a Robusta coffee plant planted in the highlands of Pinogu with an altitude of about 300 to 400 meters above sea level. This located in Tilongkabila mountain with soil type red-yellowish Alfisol (Mediteran). It has high rainfall, between 1600 to $2700 \mathrm{~mm}$ /year with an average of 2,353.6 mm/year or an

Usman, R. (2006). Hukum Hak atas Kekayaan Intelektual. Bandung: Alumni, p. 41

Irianto, H. E. (2011). Strategi Pengembangan Produk Indikasi Geografis berbasis Komoditas Perikanan Budaya. In Prosiding Forum Inovasi Teknik Akuakultur, Dec 30, 2011.

6 Ayu, M.R. (2006), Memperbincangkan Hak Kekayaan Intelektual-Indikasi Geografis, Bandung: Alumni, p. 43 
average of $196.1 \mathrm{~mm} /$ month. Have rainy days between $0-19$ rain days/month with an average of 14 days of rain/month. Have 10 wet months and 2 dry months i.e October and December.

Robusta coffee plants in Pinogu region evolved from early varieties of Robusta that went into Pinogu. These varieties have not been recognized for certain to date. It grown under shaded plants like Dadap plant. The grain of coffee is picked manually after becoming a healthy and fresh red bunch and chosen carefully by a minimum of $95 \%$ red bunch. The red bunch coffee is then processed using dry and honey techniques and dried in the sun until it reaches a maximum water content of $12 \%$.

Physical quality test and flavor of Robusta Pinogu coffee which is processed by dry and honey technique has been done in 2015 at Indonesian Coffee and Cocoa Research Center on 1 sample of Robusta Pinogu coffee in dry technique and 4 samples of honey technique. Summary of physical test results of Robusta Pinogu coffee as it processed by dry and honey techniques by Indonesian Coffee and Cocoa Research Center in Jember, Jawa Timur, Indonesia (Table 1).

Table 1. Summary of physical test results of Robusta Pinogu coffee

\begin{tabular}{|c|c|c|c|c|c|c|c|c|c|}
\hline No & $\begin{array}{l}\text { Village of } \\
\text { example origin } \\
\text { and No. } \\
\text { example }\end{array}$ & $\begin{array}{c}\text { Live } \\
\text { insect }\end{array}$ & $\begin{array}{l}\text { Odor } \\
\text { seeds }\end{array}$ & $\begin{array}{c}\text { Water } \\
\text { content } \\
(\%)\end{array}$ & $\begin{array}{c}\text { Impurity } \\
\text { content } \\
(\%)\end{array}$ & $\begin{array}{l}\text { No pass sieve } \\
6,5 \mathrm{~mm} \text { (big } \\
\text { seeds) }\end{array}$ & $\begin{array}{c}\text { No pass } \\
\text { sieve } 3,5 \\
\mathrm{~mm}\end{array}$ & $\begin{array}{l}\text { Taint } \\
\text { value }\end{array}$ & $\begin{array}{l}\text { Quality } \\
\text { (SNI) }\end{array}$ \\
\hline \multicolumn{10}{|c|}{ Dry Processing } \\
\hline 1 & $\begin{array}{c}\text { Pinogu } \\
02.15 .1 .0041\end{array}$ & 0 & 0 & 11,3 & 0 & Pass & 0 & 69,9 & $\begin{array}{l}\text { Quality 4b, } \\
\text { Small seed }\end{array}$ \\
\hline \multicolumn{10}{|c|}{ Honey Processing } \\
\hline 2 & $\begin{array}{l}\text { Tilonggibila } \\
02.15 .1 .0042\end{array}$ & 0 & 0 & 11,2 & 0 & Pass & 0 & 73,2 & $\begin{array}{l}\text { Quality 4b, } \\
\text { Small seed }\end{array}$ \\
\hline 3 & $\begin{array}{c}\text { Dataran Hijau } \\
02.15 .10043\end{array}$ & 0 & 0 & 11,5 & 0 & Pass & 0 & 54 & $\begin{array}{l}\text { Quality 4a, } \\
\text { Small seed }\end{array}$ \\
\hline 4 & $\begin{array}{c}\text { Bangio } \\
02.15 .1 .0044\end{array}$ & 0 & 0 & 11,3 & 0 & Pass & 0 & 63,9 & $\begin{array}{l}\text { Quality 48, } \\
\text { Small seed }\end{array}$ \\
\hline 5 & $\begin{array}{l}\text { Pinogu } \\
\text { Permai } \\
02.15 .1 .0045\end{array}$ & 0 & 0 & 11,3 & 0 & Pass & 0 & 47,5 & $\begin{array}{l}\text { Quality 4a, } \\
\text { Small seed }\end{array}$ \\
\hline
\end{tabular}

Source: Primary data (edited), 2016.

Summary of test results of Robusta Pinogu coffee as it processed with dry and honey techniques by Indonesian Coffee and Cocoa Research Center in Jember are shown in Table 2. In physical testing result seen that Robusta Pinogu coffee has physical quality in grade 4 with small seeds. Robusta Pinogu coffee which is processed using dry technique has 84 flavor test value, and Robusta Pinogu coffee which is processed by using honey technique has flavor test value ranged from 80.75 until 81.75 no taints.

All samples of Robusta Pinogu coffee tested have excellent flavor and have chocolate flavor. Flavor test for Robusta Pinogu coffee through dry test will be done replicate to get a better-quality flavor. The results of additional flavor testing will be submitted to the Ministry of Justice and Human Rights. However, to see clearly the pattern of flavor of Robusta Pinogu coffee, these values are transformed into a diagram of Robusta Pinogu coffee flavor. It is seen that the five examples of Robusta Pinogu coffee have the same flavor pattern. 
Table 2. Summary of flavor testing result of Robusta Pinogu coffee

\begin{tabular}{|c|c|c|c|c|c|c|c|c|c|c|c|c|c|}
\hline No & $\begin{array}{c}\text { Village of } \\
\text { example } \\
\text { origin and } \\
\text { No. example }\end{array}$ & Fr & $\mathrm{Fl}$ & Aft & Sal & Bit & Mo & Uni & Bal & Cle & Ov & Fin Scr & Flavor \\
\hline \multicolumn{14}{|c|}{ Dry processing } \\
\hline 1 & $\begin{array}{c}\text { Pinogu } \\
02.15 .1 .0041\end{array}$ & 7,75 & 7.75 & 7,75 & 7,50 & 7,50 & 8,00 & 10,0 & 8,00 & 10,0 & 7,75 & 84,00 & Chocolate \\
\hline \multicolumn{14}{|c|}{ Honey processing } \\
\hline 2 & $\begin{array}{l}\text { Tilonggibila } \\
02.15 .1 .0042\end{array}$ & 7,75 & 7,50 & 7,50 & 7,50 & 7,50 & 7,75 & 10,0 & 7,50 & 10,0 & 7,50 & 80,75 & Chocolate \\
\hline 3 & $\begin{array}{c}\text { Dataran } \\
\text { Hijau } \\
02.15 .10043\end{array}$ & 8,00 & 7,75 & 7,75 & 7,50 & 7,50 & 7,75 & 10,0 & 7,75 & 10,0 & 7,75 & 81,75 & $\begin{array}{c}\text { Dark } \\
\text { Chocolate }\end{array}$ \\
\hline 4 & $\begin{array}{c}\text { Bangio } \\
02.15 .1 .0044\end{array}$ & 8,00 & 7,50 & 7,50 & 7,75 & 7,75 & 7,50 & 10,0 & 7,50 & 10,0 & 7,50 & 81,00 & $\begin{array}{c}\text { Dark } \\
\text { Chocolate }\end{array}$ \\
\hline 5 & $\begin{array}{c}\text { Pinogu } \\
\text { Permai } \\
02.15 .1 .0045\end{array}$ & 8,00 & 7,75 & 7,75 & 7,50 & 7,50 & 8,00 & 10,0 & 7,75 & 10,0 & 7,75 & 81,75 & $\begin{array}{l}\text { Caramelly, } \\
\text { Chocolate }\end{array}$ \\
\hline
\end{tabular}

Note:

$\mathrm{Fr}=$ Fragrance $\mathrm{Fl}=$ Flavor; $\mathrm{Aft}=$ Aftertaste; Sal = Salt $/$ Acid $;$ Bit = Bitter $/$ Sweet Mo = Mouthfeel $/$ Body;

Uni = Uniformity Cups; Bal = Balance; Cle = Clean Cups; Ov = Overall

Final Score: 6.00-6.75 = Good; 7.00-7.75 = Very Good; 8.00-8.75 = Excellent; 9.00-9.75 = Outstanding

All samples: No taints/faults

The information clearly states that Robusta Pinogu coffee, though processed using different processing techniques still has the same flavor pattern, so it can use similar geographical indication. The flavor diagram of Robusta Pinogu coffee is shown in Figure 1.

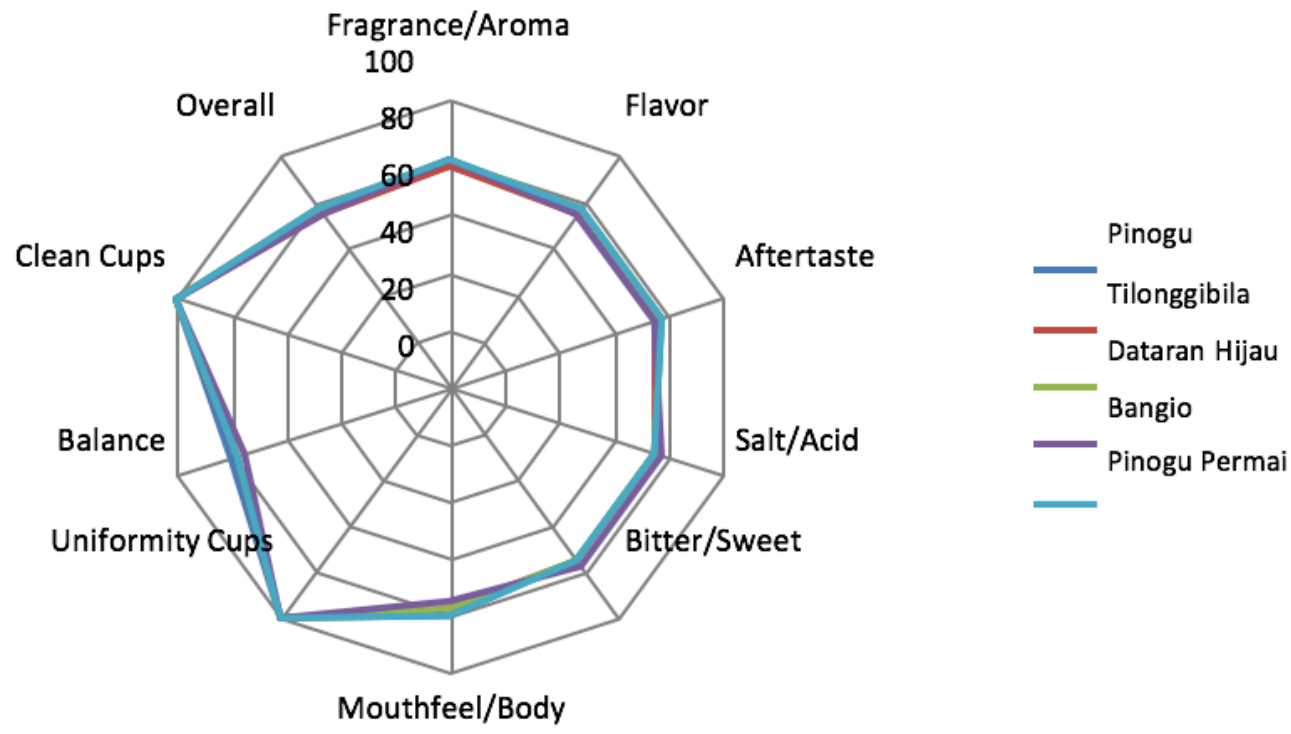

Figure 1. Flavor diagram of Robusta Pinogu coffee 


\section{Historical Review of "Pinogu Coffee"}

Renal Komendangi, he is a Suwawa community leader aged 80 years old, in Pesona Kopi Pinogu, stated that it is difficult to ascertain when the coffee plant begins to be cultivated by Pinogu' peoples. It is estimated that the coffee plant began to enter Gorontalo region including Pinogu in the Dutch era and is estimated since around the 1800s Pinogu people have cultivated coffee plant. ${ }^{7}$

Elder Pinogu said that the inclusion of the coffee plant to Pinogu came from the visit of a community leader named Abdullah Datau, the husband of late siblings Nani Wartabone, he is an independence patriot from Gorontalo, visited to Dolundu'o, Kotamobagu, Bolaang Mongondow. Upon returning from Kotamobagu, he brought coffee beans as souvenirs cultivated in Pinogu, Tapada' a and Olile. Another version said that the coffee plant entered the Gorontalo region is currently brought by Dutch traders. Officially, the Dutch entered the Gorontalo in 1677. In 1705, the Dutch established the Trade Office in Gorontalo. In 1879, the Dutch entrepreneurs entered liberika coffee into the Pinogu region. At the moment, Pinogu' liberika coffee is favorite coffee drink of Wilhelmina queen in the Netherlands. However, the further development plan of the liberika coffee in Pinogu was unsuccessful, as it was not supported by King Tangahu of the Tuwawa/Bangiya kingdom.

In 1960s, Pinogu peoples with the head of Suwawa subdistrict brought and developed robusta coffee seedlings from Kotamobagu Bolaang Mongondow. In the early 1970s or around 1972s, the PRPTE project of the Directorate General of Plantations sent thousands of robusta coffee seedlings to the Pinogu community. Because there are no adequate road facilities, the development of Robusta coffee cultivation is not continuous. Efforts to regenerate robusta coffee cultivation began in 2010. In that year the peasant community in Pinogu intends to change its activities from simply being a coffee collector to a farmer producing coffee. At that time the intention was just like a dream in the daytime because remember the road is really heavy and difficult to follow, also very far from the hustle and bustle of the development of the province.

Thanks to the God Almighty, in November 2012, the local government of Bone Bolango Regency as it facilitated by the Head of Agriculture Agency of Food Security and Livestock of Bone Bolango Regency at that time, Ir. Ishak Ntoma, M.Si, together with his staff conducts a research about the potential of region and nature in Pinogu region. From several field trips emerge a study that suggested the Pinogu community to empower the existing natural potential, especially in the form of hundreds of hectares of existing coffee plants but not groomed and grow wild.

In the early 2013, Pinogu peoples try to produce robusta coffee traditionally with his guidance by establishing a coffee farmers group. As his suggestion, the coffee products of Pinogu peoples ought to name and since it has the name of the produced coffee products become increasingly popular in the market. At that time, the introduced name was Robusta Pinogu coffee. On March 5, 2013, Robusta Pinogu coffees were brought directly by the regent of Bone Bolango along with his team to be included at the event of "International Tourisme Borsc (ITB) in Berlin". Apparently at the event the Pinogu coffee became a newcomer who many devotees in the international business coffee scene.

7 Mobiliu, A. (2015). Pesona Kopi Pinogu. Gorontalo: PGRI-Gorontalo Press, p. 56-57. 
Miss Coffee Indonesia is also tempted to hear, see, and feel the quality and uniqueness of Pinogu Coffee, so appear desire to come to Pinogu Bone Bolango, even from the event promised to bring Pinogu coffee as one of the ambassadors Coffee from Indonesia, especially from Bone Bolango. Since the Robusta Pinogu coffee became an icon of Bone Bolango Regency and also directly brought the name of Pinogu subdistrict as an area that has been isolated and unknown, it has Robusta coffee with international quality.

On 21 April 2013, Robusta Pinogu coffee was launched by Minister of State-Owned Enterprises of the Republic of Indonesia Mr. Dahlan Iskan, at the event of "Penanaman Padi Bersama" and launch Pinogu coffee in Toluwaya village, Tapa subdistrict, Bone Bolango Regency. Currently, the marketing of Robusta Pinogu has penetrated the province of Gorontalo. Also, demand arises from abroad, but cannot be served due to production level. This situation is increasingly open employment and entrepreneurial world for Pinogu society and for society in Bone Bolango district in general.

Although Pinogu Robusta coffee is well known, but to date no further research has been done on the origin of robusta coffee in Pinogu, as well as its varieties. In the planting area of robusta coffee in Pinogu can be found also the type of liberika coffee, but Pinogu peoples have been able to distinguish between the types of robusta coffee with liberika, so that in the production of Robusta Pinogu coffee is not mixed with liberika coffee type.

\section{Social and Cultural Analysis}

From the past to the present in cultivating or celebrating the big days and marriages of Pinogu community are using a mutual assistance system. Local people call this tradition as Hulunga or Gulunga which is more or less has same meaning as Mohuyula (mutual assistance) in Gorontalo valley.

The past, the supervision and control of all pants is under the Panggoba system played by someone who controls astrology and all forms of plant pests and diseases. Panggoba has the ability to move pests or plant diseases from one place to another or disease from one person to another. In Pinogu society, there is also Talenga position. Talenga has two functions, namely as a commander and also as a reader of natural signs. The skill of reading these natural signs is used by people to predict the weather and rainfall. Talenga expertise inherited from generation to generation. Anyone has the right to be Talenga as long as they have talent and ability to learn the science of Talengan arts.

Currently to produce Robusta Pinogu coffee raw material in the form of robusta coffee with healthy and fresh red bunch, robusta coffee farmers join in farmer groups. To carry out the activities of the farmer group, members of the farmer groups democratically elected the farmer group members consisting of the Chairman, Secretary and Treasurer as well as the management of the sections needed to support Robusta coffee farming activities. Farmer groups also receive training facilities, tools and materials for the cultivation and processing of coffee from the local government.

Every three months once the coffee farmers, field extension officers and plantation officers discuss the most appropriate time and best ways to grow, cut, fertilize and control the pests and diseases of Robusta coffee plants. Thanks to the good cooperation between coffee farmers, field extension and plantation officers, coffee farmers are able to harvest red bunch as well as fresh processing of red coffee with dry and honey 
techniques. At present, it began to develop wet processing technique to meet consumer demand. 8

The availability of limited land encourages farmers to intensify to increase production and income from farming. Farmers also diversify the plant by combining coffee plants with other commodities such as cocoa, coconut, durian and livestock. The diversification activities result in an interesting and unique cropping system. For example, from other crops get shade, and from livestock can be produced manure, whereas livestock get their feed from the crops. Diversification also helps farmers to obtain more stable producers on a monthly basis.

Also, Pinogu area has a non-plantation farming area that mainly produces food and vegetables. Areas for crops and vegetable generally use relatively flat areas compared to areas used for plantation crops and fruits that generally use hillier and steeper terrain. The division of plantation areas and agricultural is contained in the map of the division of the Pinogu area for agriculture and plantations.

Until now, in Pinogu peoples, it is known that some activities have become community culture related to coffee, as follows:

a) Coffee becomes a traditional drink that should always be served to every guest who comes to Pinogu.

b) Coffee becomes one of the delivery materials at the event celebration, and coffee is used as a treat to guests who come at night in the event.

c) Coffee is used as a souvenir for guests who come from other regions.

d) Coffee becomes a drink that is always served at every official local government event in Bone Bolango district

\section{Planting Area of Robusta Pinogu Coffee}

Seeing from the morphology of the earth surface, most of Pinogu region is an area with a dominating topography of hilly terrain with narrow and dispersed valleys. This hilly feature is more prominent in the villages around the forest. The physical environmental conditions in Pinogu highlands are listed in Table 3.

Table 3. Physical condition of Pinogu area

\begin{tabular}{lll}
\hline Relief & Height & $300-400 \mathrm{dpl}$ \\
\hline Weather & Rainfall & $1.600-2.700 \mathrm{~mm} /$ year \\
& Temperature & $15^{\circ} \mathrm{C}$ (night) and $22-26^{\circ} \mathrm{C}$ (day) \\
& Relative humidity & $60-80 \%$ \\
\hline Soil & Topography & $\begin{array}{l}\text { Dominated by hill with narrow valleys that spread } \\
\text { and more prominent in villages around the forest. } \\
\end{array}$ \\
& Types of soil & $\begin{array}{l}\text { Alfisol (mediteran) red-yellowish with soil pH 6,25 } \\
\text { (tend to be neutral). }\end{array}$ \\
\hline
\end{tabular}

Source: Primary data (edited), 2016.

8 Sumiyati, Y., Ramli, T.A., \& Iskandar, R.K. (2008). Kajian Yuridis Sosiologis mengenai Indikasi Geografis sebagai Sumber Pendapatan Asli Daerah (PAD). MIMBAR, Jurnal Sosial dan Pembangunan, 24(1), 79-88. 
Planting area of Robusta coffee in Pinogu is an altitude area with topography conditions that vary from flat, wavy to mountainous. In these hilly and valley areas the Pinogu' peoples conduct agricultural cultivation activities, including the cultivation of robusta coffee plants. Variations in altitude between villages vary greatly, even within certain villages the height difference between farmers' plantation is also quite prominent. Commonly, the Pinogu area has three geological formations, namely sandstone, mudstone, tuff conglomerate, lapili tuff and agglomeration; the formation of raised limestone and classic limestone, as well as the formation of tuff, lapili tuff and lava.

Robusta Pinogu coffee with its unique quality and flavor can basically only be produced from ripe, red and healthy and fresh coffee fruits from robusta coffee plants grown in the Pinogu highland. Robusta coffee plants grown outside the Pinogu region cannot produce coffee with the quality and flavor of the famous Robusta Pinogu Coffee. Basically, all highlands in Pinogu can be used for Robusta coffee planting and produce Robusta Pinogu Coffee. However, because Robusta coffee plant in Pinogu is still in development stage and expansion, now Robusta coffee planting is only planted in certain area in Pinogu.

In the early 2013, the Pinogu peoples try to produce Robusta coffee traditionally by establishing a coffee farmers group. Head of Agriculture, Plantation, Livestock and Food Security of Bone Bolango Regency suggested that coffee product of Pinogu community should be named. Since its name the coffee product has become more popular in the market. The introduced name at that time was Robusta Pinogu coffee.

\section{Conclusion}

The presence of the Geographical Indication of Robusta Pinogu Coffee, the Robusta Pinogu coffee in the market will be more secure than counterfeiting by parties who are not entitled to use the mark of Geographical Indication of Robusta Pinogu Coffee. Also, the Geographical Indications Robusta Pinogu Coffee is expected to increase the income and prosperity of communities in particular, as well as the communities of Bone Bolango and Gorontalo Province in general.

\section{References}

Ayu, M.R. (2006). Memperbincangkan Hak Kekayaan Intelektual-Indikasi Geografis, Bandung: Alumni.

Irianto, H. E. (2011). Strategi Pengembangan Produk Indikasi Geografis berbasis Komoditas Perikanan Budaya. In Prosiding Forum Inovasi Teknik Akuakultur, Dec 30, 2011.

Mobiliu, A. (2015). Pesona Kopi Pinogu. Gorontalo: PGRI-Gorontalo Press.

Rahmatullah, I. (2014). Perlindungan indikasi geografis dalam hak kekayaan intelektual (HKI) melalui ratifikasi perjanjian lisabon. Jurnal Cita Hukum, 2(2): 305-316.

Saidin, O.K. (2015). Transplantation of Foreign Law into Indonesian Copyright law: The Victory of Capitalism Ideology on Pancasila Ideology. Journal of Intellectual Property Rights, 20(4): 230-249.

Sumiyati, Y., Ramli, T.A., \& Iskandar, R.K. (2008). Kajian Yuridis Sosiologis mengenai Indikasi Geografis sebagai Sumber Pendapatan Asli Daerah (PAD). MIMBAR, Jurnal Sosial dan Pembangunan, 24(1), 79-88. 
P-ISSN: 2442-9880, E-ISSN: 2442-9899

The Directorate of General of Intellectual Property Rights the Ministry of Justice and Human Rights of the Republic of Indonesia, Kompilasi Undang-Undang Republik Indonesia di Bidang Hak Kekayaan Intelektual, Japan Internasional Co-operating Agency.

Usman, R. (2006). Hukum Hak atas Kekayaan Intelektual. Bandung: Alumni. 